九州大学学術情報リポジトリ

Kyushu University Institutional Repository

\title{
Hybrid Kiln Drying System with Radio Frequency Heating for Hinoki Boxed-Heart Timber with Round Edges
}

Piao, Jinji

Laboratory of Wood Material Technology, Division of Biomaterial Science, Department of Forest and Forest Products Sciences, Faculty of Agriculture, Kyushu University

Fuj imoto, Noboru

Laboratory of Wood Material Technology, Division of Biomaterial Science, Department of Forest and Forest Products Sciences, Faculty of Agriculture, Kyushu University

Yamamoto, Yasushi

Yamamoto Vinita Co., Ltd

Nagata, Soj i

Yamamoto Vinita Co., Ltd

https://doi.org/10.5109/12865

出版情報：九州大学大学院農学研究院紀要. 53 (2)，pp. 505-509，2008-10-28. Faculty of Agriculture, Kyushu University

バージョン :

権利関係 : 


\title{
Hybrid Kiln Drying System with Radio Frequency Heating for Hinoki Boxed-Heart Timber with Round Edges
}

\author{
Jinji PIAO", Noboru FUJIMOTO*,Yasushi YAMAMOTO ${ }^{2}$ \\ and Soji NAGATA ${ }^{2}$
}

\author{
Laboratory of Wood Material Technology, Division of Biomaterial Science, Department of Forest \\ and Forest Products Sciences, Faculty of Agriculture, Kyushu University, \\ Fukuoka 812-8581, Japan \\ (Received June 27, 2008 and accepted July 16, 2008)
}

\begin{abstract}
To avoid the formation of checks during the drying of hinoki (Chamaecyparis obtusa Endl.) boxedheart timber with round edges, a comparative investigation on the kiln drying and the hybrid drying, the high temperature and low humidity $(\mathrm{HT} / \mathrm{LH})$ treatment stage combined with radio frequency (RF) heating, was carried out in this study. The results showed that the hybrid drying could effectively prevent the occurrence of both surface checks and internal checks in the hinoki boxed-heart timber with round edges. Moreover, the hybrid drying time was significantly shortened to 15 hours. The combination of RF heating at the stage of HT/LH treatment resulted in at least following beneficial consequences: reduction of the surface temperature decreasing, attenuation of the tensile stress, promotion of the internal drying, relaxation of the moisture gradient, and inhibition on the extreme drying stress. Therefore, a wood drying strategy with high speed, free of both surface and internal checks could be realized through hybrid drying.
\end{abstract}

\section{INTRODUCTION}

During the drying of the boxed-heart timbers, surface checks often form due to obvious anisotropic shrinkage (Kanagawa, 1985). Consequently, it is necessary to develop a drying method that can effectively restrain the formation of surface checks. One currently used drying method can prevent almost all surface checking of some species of wood through treatment at the high temperature and low humidity (HT/LH) to form a large dryingset on the wood surface (Fujimoto et al., 1994; Yoshida et al., 2000). However, it is difficult for this treatment to prevent surface checking in the hinoki (Chamaecyparis obtusa Endl.) boxed-heart timber with round edges.

In our previous studies, both radio frequency heating $(\mathrm{RF})$ and microwave heating have been used to dry the heavy timbers of sugi, with the advantages of reduced processing times, consistent quality, and simplified process control. Because radio frequency heating or microwave heating occurs simultaneously throughout the thickness of the timber, the inner layer moisture content (MC) of the sugi round timber or sugi boxedheart timber was dropped far more significant by these two methods than by the kiln drying (Piao et al., 2006; 2007; 2007).

To prevent surface checking, the effects of RF heating combined with the HT/LH treatment stage during kiln drying were evaluated in this study, in order to explore a new drying strategy for the drying of hinoki boxed-heart timber with round edges.

Laboratory of Wood Material Technology, Division of Biomaterial Science, Department of Forest and Forest Products Sciences, Faculty of Agriculture, Kyushu University, Fukuoka 812-8581, Japan

Yamamoto Vinita Co., Ltd, Yao-shi, Osaka, 581-0075, Japan

* Corresponding author (E-mail: fujipon@agr.kyushu-u.ac.jp)

\section{MATERIALS AND METHODS}

\section{Materials}

Hinoki boxed-heart timbers with round edges were selected for drying tests in this experiment. The dimensions of each timber was $120 \mathrm{~mm}$ in thickness $\times 120 \mathrm{~mm}$ in width $\times 500 \mathrm{~mm}$ in length. Before testing, 20-mm thick cross sections at the points of $100 \mathrm{~mm}$ from the end of the timbers were sampled, and the initial MCs in the cross section were measured by oven-dry method. The remainder of the specimen at the length of $400 \mathrm{~mm}$ was used for the drying test after coating one end with silicone.

\section{Drying system}

Figure 1 shows the hybrid kiln drying system with

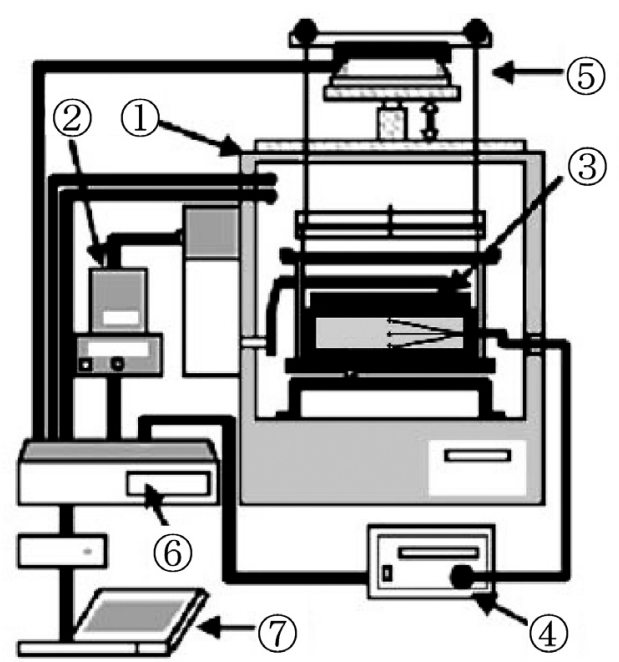

Fig. 1. Hybrid kiln drying system with $\mathrm{RF}$ heating. (1) Constant temperature \& humidity chambers (2) $\mathrm{RF}$ generator (3) Electrode plates (4) Optical fiber thermometer (5) Load cell (6) Controller (7) Notebook computer 
RF heating. The RF generator (YAMAMOTO Vinita) was installed in a constant temperature and humidity machine for this study. The radio frequency used was 13.56 MHz. The load woods were placed between the charged (+) and grounded (-) electrode plates. After separating the woods and electrode plates with wood strips of $10 \mathrm{~mm}$ thickness, the wood and electrode plates were fastened by rope. A load cell was installed on the top of the machine to lift the fastened set of woods for weighing during drying. Three optical fiber thermometers preset in holes drilled in the wood were used to measure the temperature of the top surface, center and bottom surface. The center temperature of the wood was maintained around $105-110^{\circ} \mathrm{C}$ by the operating system. During drying, the weights and temperatures of the wood were recorded every minute and logged into a computer.

\section{Drying methods}

Table 1 shows the drying methods, kiln drying and hybrid drying, as well as the drying time under each drying stage. In this study, the HT/LH treatment stage com-

Table 1. Drying condition and total drying time

\begin{tabular}{lccccc}
\hline & $\begin{array}{c}\text { Steaming } \\
\text { DBT-95 }{ }^{\circ} \mathrm{C}, \\
\text { WBT-95 }{ }^{\circ} \mathrm{C}(\mathrm{h})\end{array}$ & $\begin{array}{c}\mathrm{HT} / \mathrm{LH} \text { (DBT-120 }{ }^{\circ} \mathrm{C}, \\
\text { WBT-90 }\end{array}$ & $\begin{array}{c}\left.{ }^{\circ} \mathrm{C}\right) / \mathrm{RF} \text { heating } \\
\text { (h) }\end{array}$ & $\begin{array}{c}\text { DBT-90 }{ }^{\circ} \mathrm{C}, \\
\text { WBT-60 }{ }^{\circ} \mathrm{C} \\
(\mathrm{h})\end{array}$ & $\begin{array}{c}\text { Total drying } \\
\text { time (h) }\end{array}$ \\
\hline $\begin{array}{l}\text { Hybrid } \\
\text { drying }\end{array}$ & $\mathrm{H} 1$ & 12 & $12 / 4.8$ & - & 24 \\
\hline $\begin{array}{l}\text { Kiln } \\
\text { drying }\end{array}$ & $\mathrm{H} 3$ & 12 & $12 / 4.7$ & - & 18 \\
\hline
\end{tabular}

Note: HT/LH - high temperature and low humidity

Hybrid kiln drying with RF heating

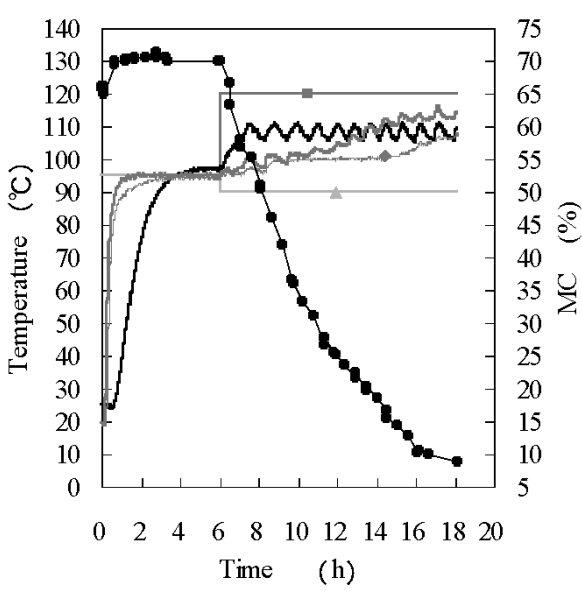

$$
\begin{aligned}
& - \text { DBT } \\
& - \text { WBT } \\
& - \text { Wood center temp. } \\
& - \text { Wood temp. of charged side } \\
& \rightarrow \text { Wood temp. of grounded side } \\
& \rightarrow \text { MC }
\end{aligned}
$$

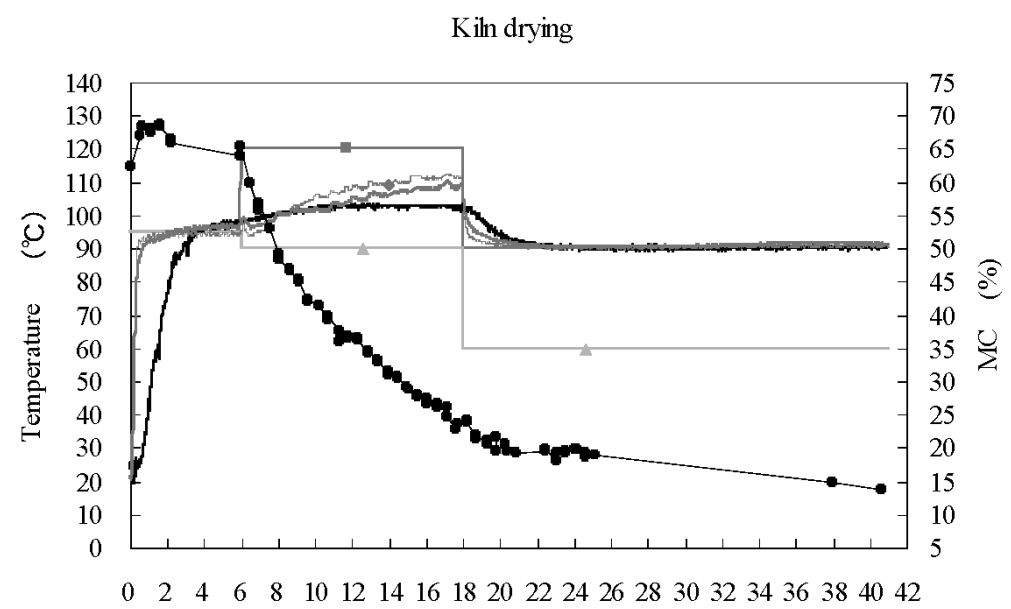

Time (h)

Fig. 2. Drying curve. 
bined with or without RF heating was comparatively carried out for drying hinoki boxed-heart timber with round edges. The timbers were first treated with $95^{\circ} \mathrm{C}$ steaming for 6 or 12 hours, followed by HT/LH treatment (DBT $120^{\circ} \mathrm{C}$, and WBT $90^{\circ} \mathrm{C}$ ) for 12 hours. In this stage of the hybrid drying, RF heating was combined with the HT/LH treatment. An additional step under DBT $90^{\circ} \mathrm{C}$ and WBT $60{ }^{\circ} \mathrm{C}$ continued until reaching a final MC below $15 \%$. For the timbers treated with combined drying, this additional step is unnecessary because the final MC has already decreased to below $15 \%$ by the combined $\mathrm{RF}$ heating.

\section{Measurements}

The MC distributions of the cross section were measured before and after drying. To determine the temperature of wood during drying process, the timbers were drilled three holes of $60 \mathrm{~mm}$ in depth at different positions on the timbers: $5 \mathrm{~mm}$ deep to the top surface and bottom surface, respectively, as well as the center. Each hole was set with one optical fiber thermometer and then sealed with silicon. The wood weights during drying were obtained every $30 \mathrm{~min}$ by the load cell that was preset on the top of the machine with constant temperature and humidity. After drying, other factors such as surface checks, internal checks, and released strains in the direction of the width, were measured according to previously described methods.

\section{RESULTS AND DISCUSSION}

\section{Temperature of timbers and drying curves}

During the kiln drying and the hybrid drying, the wood temperatures were measured continuously and the drying curves were drawn. One representative result is shown in Fig. 2. It can be seen that the total hybrid drying time was shortened significantly due to the combination with RF heating, compared to the kiln drying. The total drying time is only 15 hours, including 6 hours for steaming treatment, in the case of hybrid drying from green to a final MC below 15\%. After steaming treatment for 4-5 hours, the temperature in the wood center increased to $95^{\circ} \mathrm{C}$. During the stage of HT/LH treatment, hybrid drying quickly increased the center temperature up to $100^{\circ} \mathrm{C}$ within $16-20 \mathrm{~min}$. In the subsequent stage, the center temperature remained at a high temperature range of $105-110^{\circ} \mathrm{C}$ due to the $\mathrm{RF}$ heating. However, it took more than 3-4 hours to elevate the center temperature up to $100^{\circ} \mathrm{C}$ at the $\mathrm{HT} / \mathrm{LH}$ treatment stage of kiln drying, which remained constant until the end of this stage. These results indicated that during the kiln drying, only the wood surface could be dried quickly, while during the hybrid drying, the wood center remains a relatively higher temperature and the internal moisture can quickly move out to the surface. As a result, the moisture gradient between the center and the surface of wood became very gentle during the hybrid drying.

\section{Moisture content distribution}

After drying the timbers, the MC distributions across the cross section were monitored and the representative results are shown in Fig. 3. The average MC of the timbers dried by the kiln drying and the hybrid drying reduced from $62.3 \%$ and $66.1 \%$ to $13.8 \%$ and $8.9 \%$, respectively. After the hybrid drying, there seemed to be a slight moisture gradient between the top surface (charged) and the bottom surface (grounded), while there was no obvious moisture gradient between the center and surface of wood, as compared to the kiln drying.

\section{Surface checks, internal checks and the surface released strains}

The surface checks and the internal checks were examined after drying the timbers. As shown in the Fig. 4, kiln drying caused clear surface checks. However, hybrid drying resulted in neither observable surface checks nor internal checks.

In addition, the surface released strains after kiln drying and hybrid drying were detected to be $4200 \mu \varepsilon$ and $2800 \mu \varepsilon$, respectively, suggesting that the compression stress in kiln drying is higher than that in hybrid drying.

These results are interesting and applicable, and can be reasonably explained by the above experimental results of the temperature distribution and the MC distribution. Under the HT/LH treatment, the wood surface

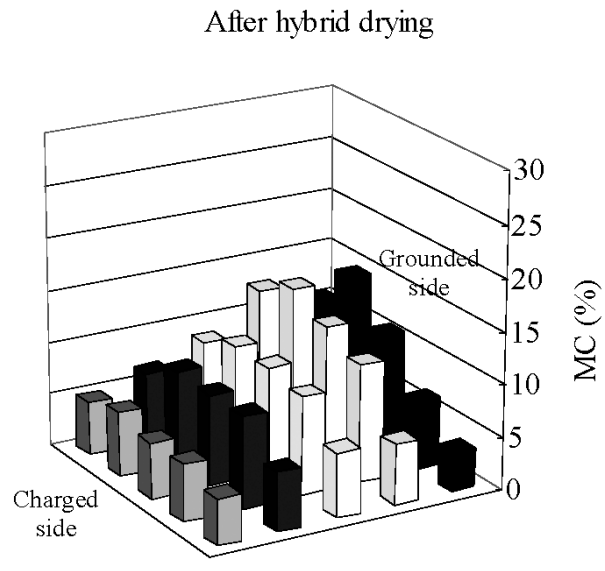

After kiln drying

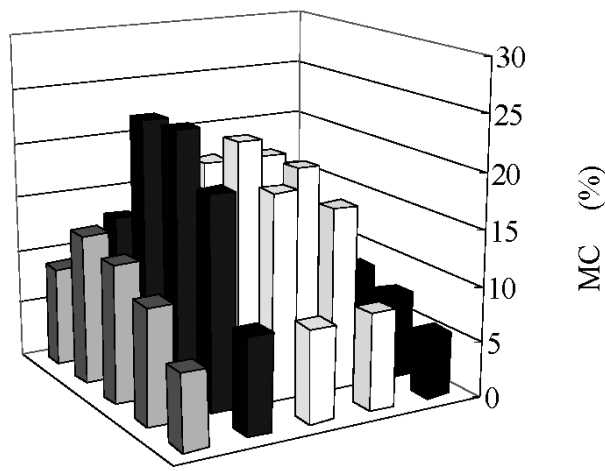

Fig. 3. MC distribution after each drying method. 
a)
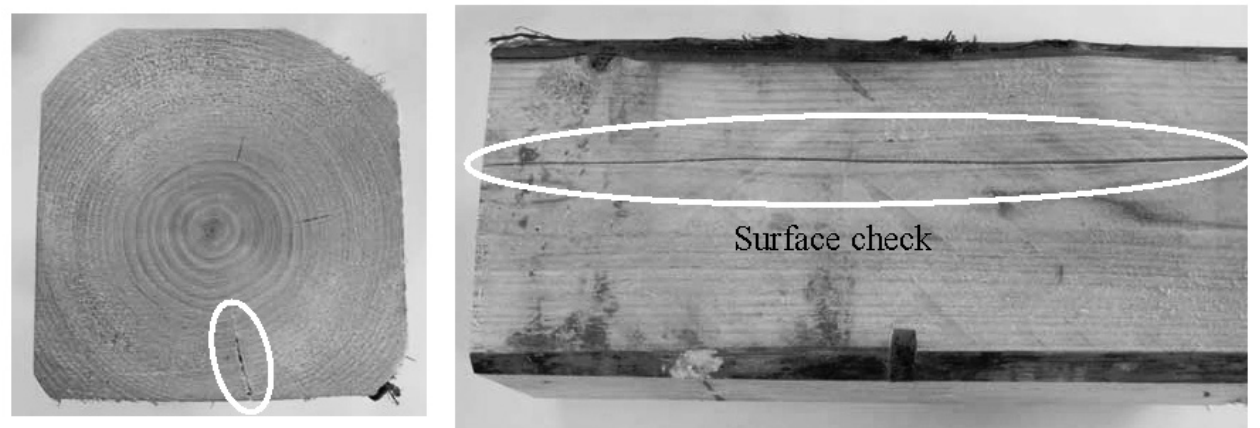

b)
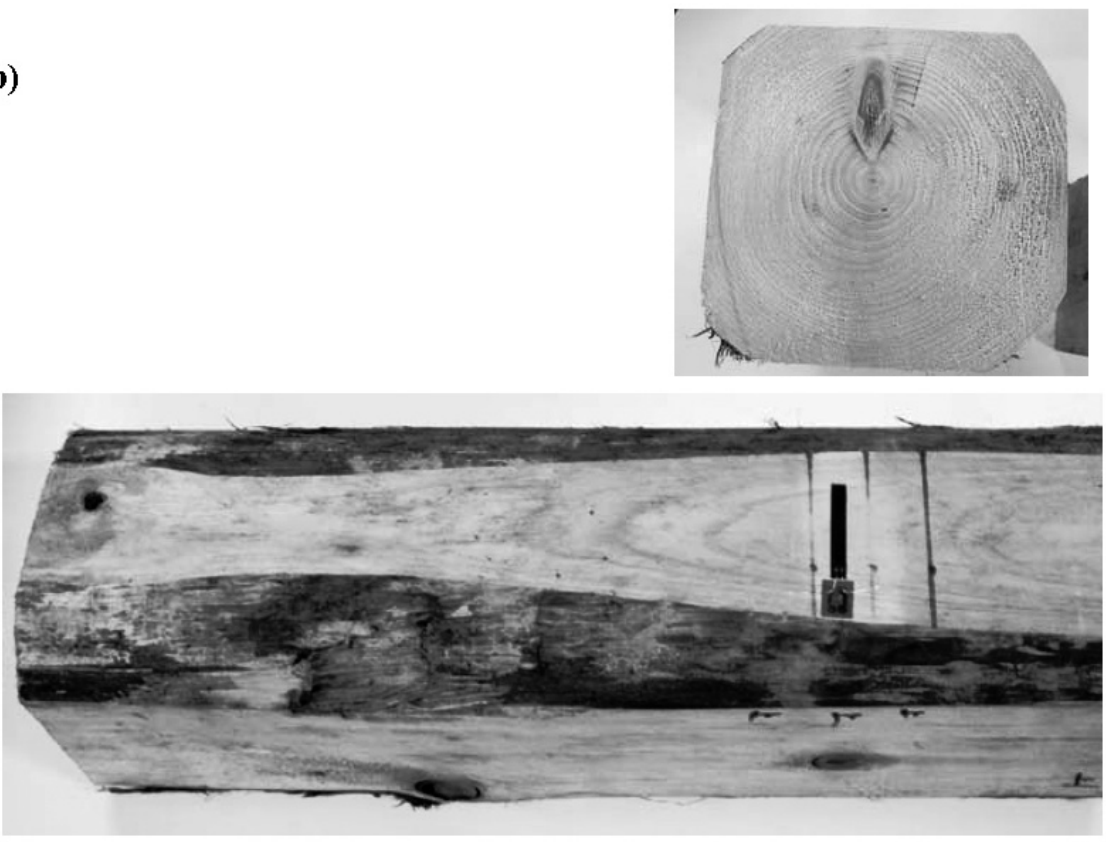

Fig. 4. Typical surface and cross section of timbers after each drying methods.

a) Surface checks on a timber after kiln drying

b) No surface and internal checks after hybrid drying

dried quickly and shrank clearly, leading to formation of tensile stress. Hybrid drying could accelerate the increasing of the surface temperature and subsequently attenuated the tensile stress. Furthermore, hybrid drying could also maintain a high center temperature in the wood and promote the movement of internal moisture towards surface, thereby prevented the formation of extreme MC gradient and drying set.

\section{CONCLUSIONS}

The effects of RF heating combined with the HT/LH treatment stage during kiln drying were evaluated and a new drying strategy was established for the drying of hinoki boxed-heart timber with round edges. The conclusions of the study are as below:

1. Hybrid kiln drying system, HT/LH treatment stage combined with RF heating, could effectively prevent the occurrence of both surface checks and internal checks in the hinoki boxed-heart timber with round edges.
2. The hybrid drying time was significantly shortened to 15 hours.

3. The hybrid drying resulted in reduction of the surface temperature decreasing, attenuation of the tension stress, promotion of the internal drying, relaxation of the moisture gradient, and inhibition on the extreme drying stress.

4. The hybrid Kiln drying system with RF heating can be explored as a new drying strategy for the drying of hinoki boxed-heart timber with round edges.

\section{REFERENCES}

Fujimoto, N., H. Fujimoto, J. Kawabe and Y. Mataki 1994 Drying of boxed heart square timbers I. - Changes of surface stress and cross-sectional shrinkage of dehumidifier kiln-dried timbers of sugi. Mokuzai Gakaishi, 40(7): 758-765

Kanagawa, Y 1985 Radio frequency/vacuum drying of wood - 3 Application to the sugi boxed-heart square timber. MOKUZAI $K O G Y O, \mathbf{4 0}(\mathbf{2})$ : $66-70$ 
Piao, J., N. Fujimoto, K. Oohashi, M. Tanikawa, M. Kitada, H. Sonobe and Y. Ueda 2006 Drying properties of sugi round timber with microwave heating. J. Fac. Agr., Kyushu Univ., 51(2): 345-349

Piao, J., N. Fujimoto, K. Oohashi, M. Tanikawa, M. Kitada, H. Sonobe and Y. Ueda 2007 Effect of a microwave drying process as a pretreatment for preservative impregnation on sugi round timbers. Wood Preservation, 33(3): 117-125

Piao, J., N. Fujimoto, Y. Yamamoto and S. Nagata
Development of hybrid kiln drying system with radio frequency heating for the sugi boxed-heart timber. J. Fac. Agr., Kyushu Univ., 52(1): 117-121

Yoshida, T., T. Hashizume and N. Fujimoto 2000 Hightemperature drying characteristics on boxed-heart square timber of karamatsu and sugi - Influences of high temperature conditions with low humidity on drying properties -. MOKUZAI KOGYO, 55(8): $357-362$ 